Journal of Maternal and Child Health (2016), 1(4): 257-267

https://doi.org/10.26911/thejmch.2016.01.04.07

\title{
Implementation of Basic Obstetric and Neonatal Emergency Service Program (PONED) at Health Centers, Tegal
}

\author{
Sri Tanjung Rejeki ${ }^{1)}$, Muhammad Akhyar ${ }^{2)}$, Supriyadi Hari Respati ${ }^{3}$ ) \\ ${ }^{1)}$ School of Health Sciences Bhakti Mandala Husada, Slawi, Central Java \\ 2)Masters Program in Public Health, Universitas Sebelas Maret \\ 3)Department of Obstetrics and Gynecology, Dr. Moewardi Hospital, Surakarta
}

\begin{abstract}
Background: Maternal mortality reached 33 cases in Tegal in 2015. Some measures had been taken to reduce maternal mortality rate and infant mortality rate, among others was basic obstetric and neonatal emergency service program (PONED). The PONED program was operated by health centers with inpatients services 24 hours a day and 7 days a week. This study evaluated the Implementation of Basic Obstetric and Neonatal Emergency Service Program (PONED) at Health Centers, Tegal.

Subjects and Method: This was an evaluation study with qualitative approach and context, input, process, product (CIPP) framework. This study was conducted in Tegal, Central Java. A total of 10 key informants, including Head of Family Health and Nutrition Division at the District Health Office Tegal, Head of Health Centers, Midwife responsible for operating PONED, mothers with post heavy pre-eclampsia, were selected for this study. The data were collected by in-depth interview, observation, and document review.

Results: From the context perspective, the objective of PONED at the health centers conformed with the policy. The number of health personnel was sufficient. But nurses have not been involved in the PONED health centers. There was no special fund for operating PONED health centers. The number of facilities was sufficient. From the input perspective training on emergency service had been well carried of. An effort to increase facilities had been plan from the process perspective the health centers PONED services had conformed with the SOP. The health personnel performed task according to the job description. Intersectoral collaboration and program were well implemented. The impeding factors included the long process of BPJS claim, and low community awareness. From the product perspective, patients reported high satisfaction of the health centers PONED services.
\end{abstract}

Conclusion: The basic obstetric and neonatal emergency services program (PONED) has been well implemented in Tegal.

Keywords: PONED program, evaluation, CIPP, maternal mortality

\section{Correspondence :}

Sri Tanjung Rejeki. School of Health Sciences Bhakti Mandala Husada, Slawi. Email: sritanjungrejeki@yahoo.co.id.

\begin{tabular}{l}
\hline BACKGROUND \\
In the 2010-2014 National Medium Term \\
Development Plan (RPJMN), the goal of \\
health development is to increase life ex- \\
pectancy, reduce maternal mortality, re- \\
duce infant mortality, reduce the preva- \\
lence of malnutrition in children under five, \\
and reduce total birth rates (RPJMN, 2013) \\
The Indonesian Demographic and Health
\end{tabular}

Survey (IDHS) shows the Maternal Mortality Rate (MMR) in 2012 was 359/ 100,000 live births. Whereas in 2007 was 228/ 100,000 live births and in 2015 Millennium Development Goals (MDGs) target was 102/ 100,000 live births.

The most common causes of maternal mortality in Indonesia are postpartum hemorrhage, hypertension, pregnancy infec- 
tions such as septic abortion and puerperal sepsis, hemorrhage during pregnancy (antepartum), infections that are not due to pregnancy, and complications that exist before pregnancy.

One of the causes of maternal mortality is preeclampsia. Preeclampsia is an acute complication of pregnancy and can occur in ante, intra, and post partum. The clinical symptoms of preeclampsia can be divided into mild preeclampsia and severe preeclampsia (Prawirohardjo, 2009).

Based on data obtained from the Tegal District Health Office in 2014, the maternal mortality rate was 47 people, the causes of maternal mortality such as preeclampsia/eclampsia were 12 (25.5\%), decom was 9 people (19\%), bleeding was 8 people (17\%) pulmon oedem was 6 people (13\%) and other causes was 12 people (25.5\%). Whereas in 2015, the maternal mortality rate was 33 people with mortality caused by preeclampsia / eclampsia was 7 people (21.2\%), mortality caused by hemorrhage was 8 people (24.2\%), mortality caused by decommissioning was 6 people (24.2\%), mortality caused by pulmonary disease was 3 people (9.1 people) (9.1\%), and mortality caused by other causes was 9 people (27\%).

Looking at the problems we face in an effort to accelerate the decline in MMR and IMR, including NMR, which is so complex, it requires more rigorous efforts and support from all stakeholders, both central and regional. One effort that has been carried out to accelerate the reduction of MMR and NMR through emergency obstetric and neonatal treatment/complications at the basic service level is through efforts to implement a health center capable of Basic Obstetric and Neonatal Emergency Service Program (PONED). PONED Health Center is expected to be a reference before hospital to deal with emergencies that occur in pregnancy, childbirth, and puerperium (Ministry of Health, 2013).

PONED Health Center is an inpatient health center that is able to hold obstetric and neonatal emergency services or basic level complications 24 hours a day and 7 days a week (RI Ministry of Health, 2013). The number of community health centers in Tegal District is 29 and 10 PONED health centers.

Due to the high MMR in Tegal, one of the causes was preeclampsia, so a program evaluation study was conducted which aimed to determine the effectiveness of the PONED program at the Tegal Health Centers. The evaluation method used was the CIPP evaluation method (context, input, process, product) proposed by the stufflebeam. The CIPP method is a decision oriented evaluation approach structured to provide assistance to administrators or decision makers. Stufflebeam argues that the evaluation results will provide an alternative problem solving for decision makers.

The purpose of this study was to analyze the effectiveness of the PONED program at the Tegal Health Centers, Central Java.

\section{SUBJECTS AND METHOD}

This study was a qualitative study using CIPP evaluation methods (context, input, process, and product). The data collection was done by in-depth interviews, observation, and document studies. The informants in this study consisted of 10 people, namely Head of Family Health and Nutrition Division at the District Health Office Tegal, Head of Health Centers, midwifes responsible for operating PONED, mothers with post severe pre-eclampsia who had received health services at the PONED health centers. 
Journal of Maternal and Child Health (2016), 1(4): 257-267

https://doi.org/10.26911/thejmch.2016.01.04.07

\section{RESULTS}

\section{A. Context \\ 1. Policies and objectives of the PONED health centers}

Policy is a speech or writing that provides general instructions about setting a scope that gives a general boundary and direction for someone to move to declare the PONED health center policy refers to government policy in implementing PONED health centers. The decision letter for organizing a PONED health center came from the direct regent. One of the objectives of the PONED health center was PONED health as a place for intermediary referrals, so PONED health centers would have more capabilities than outpatient health centers and birthready health centers.

Midwives needed to know clearly about the standards and objectives of the policy because unclear standards and policy objectives were one of the factors that make the midwife's ineffectiveness in implementing the PONED program.

\section{Quality of HR}

Human resources (HR) were the most important assets to support the success of an organization. HR was the executor of all organizational policies. The success of a program would not succeed without the support of human resources with sufficient quality and quantity. The quality of human resources was related to skills, dedication, professionalism, and competence in their fields, while quantity was related to the amount of human resources, was it enough to cover all target groups or not. Human resources greatly influenced the success of the program. Without reliable human resources, the program would run slowly.

\section{Availability of Funds}

The budget related to capital adequacy or investment in a program or policy to ensure the implementation of policies. Without adequate budget support, the program would not run effectively in achieving its goals and objectives. All informants said that the PONED health center funding came from the receipt of health centerboth from retribution, JKN (National Health Insurance), and from the program budget and from the Regional Public Service Agency (BLUD).

\section{Availability of Facilities}

PONED health center required facilities such as the availability of rooms, equipment, and medicines. Completeness of tools and medicines was needed in handling emergencies. In terms of facilities, all PONED health centers already had complete facilities such as the presence of action rooms, equipment, and medicines in handling severe pre-eclampsia. They were also available in 24 hours and also ambulances with the drivers if needed.

\section{Organizational Structure}

According to Ivancevich (2008), organizational structure is the process of determining decisions to choose alternative positions, work projects, and departments. Thus, the decisions or actions chosen will produce an organizational structure. In two health centers, the organizational structure was separate from outpatient health centers; only one health center was still united. With the organizational structure there would be clarity of position. Clarity of one's position in the organizational structure would make it easier to coordinate and connect because of the linkage between the completions of a function entrusted to someone.

\section{B. Input \\ 1. Efforts to improve the quality of human resources}

The quality of human resources must always be improved; one of them was by following training to improve skills and knowledge. In order to improve knowledge and skills, the PONED Community Health 
Center engaged health workers in emergency training and by holding an emergency drill. An Emergency Drill was a special activity to assess the alertness of groups of workers when they face an emergency that could occur at any time in their workplaces and beyond. Drill emergency was carried out routinely in PONED health centers with the aim of improving and maintaining staff skills to be always ready in every emergency case.

\section{Efforts to improve facilities}

Improvement or purchase of infrastructure facilities was budgeted annually in the initial planning. The Health Office only provides in accordance with the minimum standards required by the health centerat the start of the establishment of the PONED health center. In accordance with its development, the provision of facilities and infrastructure for health center had its own budget through the budget of the Regional Public Service Agency.

PONED health center was part of the obstetric and neonatal service network. However, there were several development criteria to ensure quality, including availability, completeness, and adequacy of medical devices and medicines. Tools and medicines were conditions that must be met by PONED health centers.

\section{Process}

\section{The services of PONED health center for patients with severe preeclamsia were carried out in accordance with the SOP}

Management of severe preeclampsia in PONED health center was in accordance with the existing SOP by stabilizing it first, such as installing an IV, placing a catheter, giving a tablet of nifedipine, giving $\mathrm{MgSO}_{4}$, and then monitoring the breathing and immediately referring to the hospital.

Based on Ministry of Health Regulation 1464/2010 article 10 paragraph 3, midwives in providing maternal health services were authorized to handle emergency services, followed by referrals. To handle cases of severe preeclampsia must be carried out according to the SOP, and the SOP used in the PONED health center was Guidance from the EMAS program.

\section{Service implementation in accord- ance with the job description}

All PONED health centers that had been studied had a job description. The division of tasks of PONED health center was divided into three teams, namely the red, green and yellow teams. Each team had different duties and responsibilities. The tasks of the red team (coordinator) were to deal with and calm patients and families, direct anamnesia, do early checkups, make clinical decisions, coordinate early management, install IVs, take blood samples, follow doctor's instructions, and stay with patients.

The tasks of the yellow team were to prepare a troley emergency table (every change of office, after each action), bring an emergency push desk to the scene, make joint observations, together with the coordinator accompany the patient, document all actions and observations and prepare medicines and fluids (during emergencies). The tasks of the green team were to carry out tools such as infusion poles, suction units, provide information and call for doctors, contact and if necessary take laboratory results.

\section{Cooperation}

Parties who could cooperate with PONED health centers include cross-sectoral, health professional organizations, community and religious leaders, NGOs or concerned communities, and mass media in their working areas. All of the PONED health centers studied had collaborated cross programs and cross sectors. Cross programs were carried out by midwives and cadres when 
conducting classes for pregnant women to provide counseling, both those who were at high risk or not about the existence of PONED health centers. Whereas across sectors such as districts and village heads were gathered to be given information about the existence of PONED health centers that were ready to serve 24 hours.

\section{Inhibiting factors of the implementation of PONED health centers}

The inhibiting factor would affect the service of the PONED health centers, so it had to be addressed immediately so that the quality of service became better. These obstacles were caused by the commitment of health workers who were not yet $100 \%$, the low public awareness to deliver at the puskesmas, doctors were not in the health centerwithin 24 hours, the BPJS (Social Insurance Administration Organization) claims were too long.

\section{Products}

\section{Client's satisfaction on PONED health center services}

Satisfaction was one's feelings after comparing the performance (results) that were felt with their expectations. Based on the results of interviews, all patients said that they were satisfied with the services provided by health workers in the PONED health center.

\section{The benefits of having PONED health centers}

Based on the results of the study, the benefits of the PONED health center were to improve the skills of health workers and compliance with the SOP whether patients with severe preeclamsia before referral had been stabilized or not. With the existence of the PONED health center, in 2016 there was no mortality in community health center ' $\mathrm{P}$ ' and there were one death in community health center ' $\mathrm{T}$ ' due to Premature Rupture of The Membrane (PROM). In 'B' community health center there were 2 deaths due to hemorrhage and severe preeclamsia and all deaths occurred in the hospital.

\section{DISCUSSION}

\section{A. Context}

\section{a. Policies and objectives of the health centers}

The PONED Health Center policy refers to government policies in implementing PONED health centers. One of the objectives of the PONED health centers is that the PONED health center is a place for intermediary referrals, so PONED health centers have more capabilities than outpatient health centers and birth-ready health centers.

\section{b. Quality of Human Resource}

$\mathrm{HR}$ is the executor of all organizational policies. The quality of human resources is related to skills, dedication, professionalism, and competence in their fields. Meanwhile, strength is related to the number of human resources, is it enough to cover all target groups or not.

According to the Ministry of Health (2010), the core team in the PONED health center consists of one doctor, one nurse, and one midwife. However, based on the results of interviews, the three health workers in the health center such as doctors and midwives are already exist. However, nurses have not been involved in PONED health centers, nurses are only placed in hospitalization.

This is in line with the study of Handayani et al., (2009), which stated that health workers are a strategic resource. As a strategic resource, health workers are able to optimally use physical and financial resources in the work team.

HR or health workers at the health centers act as implementers of health services. In this role, the main tasks and 
functions of health workers are expected to be in accordance with the education and skills they have.

The quality of human resources needed at PONED health centers is health workers who have good competencies, such as trained PONED health center management, Training for Emergency Treatment of Obstetrics and Neonatal (PPGDON training), asphyxia management, and LBW management. Based on the results of the study, all the core teams in the PONED health center already have PONED training certificates from the Secondary Clinical Training Center (P2KS) Semarang.

\section{c. Availability of Funds}

The budget relates to capital adequacy or investment in a program or policy to ensure the implementation of policies. Without adequate budget support, the program will not run effectively in achieving its goals and objectives.

This is in line with Wijaya's study (2012), which stated that the obstacle in preparing PONED health centers is that there are no funds, human resources, and infrastructure that does not meet the standards. The allocation of special funds for the PONED program is also the most important factor. With the existence of these funds, PONED activities can be carried out because they can meet the procurement of emergency equipment and drugs needed in handling emergency cases.

\section{d. Availability of facilities}

PONED health center in its implementation requires facilities such as the availability of rooms, equipment, and medicines. In terms of facilities, all PONED health centers already have complete facilities such as room for action, equipment, and medicines. Handling of severe preeclamsia is also available complete with an ambulance and driver and is available in 24 hours.
This is in accordance with Handayani's study which stated that a program must be supported by the availability of facilities and infrastructure. Without the availability of facilities and infrastructure, work tasks cannot be completed as they should or the work cannot be done. Availability of facilities and infrastructure is a determinant of performance.

This is supported by Muslimah (2011), who stated that available facilities should be in sufficient quantities and types and are always in a ready to use condition so that they can help implement an action.

\section{e. Organizational structure}

According to Ivancevich (2008), organizational structure is the process of determining decisions to choose alternative positions and work projects.

In two health centers, the organizational structure was separate from outpatient health centers, only one health center was still united. With the organizational structure there will be clarity of position. Clarity of one's position in the organizational structure will make it easier to do coordination and connection because of the linkage between the completion of a function entrusted to someone.

This is in accordance with Handayani's study, which stated that one of the factors that supported the PONED program run well at the health center is the complete PONED organizational structure. So, the existence of the program can be well organized and has clear goals and steps that give a real picture to the members of the organization.

\section{INPUT}

\section{a. Efforts to improve the quality of human resources}

The PONED health centers include health workers in emergency training and conduct an emergency drill to improve their knowledge and skills. 
According to Moekijat (2003), training is a part of education that involves the learning process to acquire and improve skills outside the prevailing education system in a relatively short time and with methods that prioritize practice rather than theory. Training activities are a process of helping participants learn to gain effectiveness in doing work both now and in the future through the development of habits of thought and actions, skills, knowledge, and attitudes.

This is in line with Endang's (2009) study, which stated that midwives who have participated in training have better skills compared to midwives who have not attended training.

\section{b. Efforts to improve facilities}

Improvement or purchase of infrastructure facilities is budgeted annually in the initial planning. The Health Office only provides in accordance with the minimum standards required by the health centers at the start of the establishment of the PONED health center. In accordance with its development, the provision of facilities and infrastructure for health centers has its own budget through the budget of the Regional Public Service Agency (BLUD).

According to the study conducted by Mujiati et al., (2014), the low availability and adequacy of tools and drugs can lead to not optimal service or treatment that can be done if tools and drugs are available and complete. Infrastructure facilities must always be improved to support quality health services.

\section{PROCESS}

a. PONED health center services for patients with severe preeclamsia are carried out in accordance with the SOP

Management of severe preeclampsia in PONED health center is in accordance with existing SOPs, namely doing stabilization first such as installing an IV, placing a catheter, giving a tablet of nifedipine, and giving $\mathrm{MgSO}_{4}$ then monitoring breathing and immediately referring to the hospital.

According to Tjipto Atmoko, the Standard Operating Procedure is a guideline or reference for carrying out work duties in accordance with the functions and tools for evaluating the performance of government agencies based on technical, administrative and procedural indicators according to work procedures, work procedures, and work systems in the work unit concerned.

With the SOP, implementers can optimize the available time and can function to standardize the actions of officials in a complex and widespread organization, so that it can lead to great flexibility and great similarity in the application of regulations.

\section{b. Service delivery in accordance with the job description}

All PONED health centers studied have a job description. The division of tasks within the PONED health center is divided into three teams, namely the red, green and yellow teams, each team has different duties and responsibilities.

According to Stone (2005), job description is a written statement that explains why the job exists, what the job holder actually does, how they do it, and in what conditions the work is done. With the job description, health workers will work according to their respective duties and responsibilities so that when they take action they are more directed and well organized so that patients can be handled quickly and accurately.

This is in line with the study of Handayani et al., (2008), which stated that job descriptions are one of the items in the activity of division of tasks in the health centerin addition to the activity schedule per officer and per activity. The division of task is one of the activities in the imple- 
mentation and control of the management of the health center. With the job descripttion it will cause health workers to understand their role in implementing services.

\section{c. Cooperation}

Parties who can collaborate with PONED health centers include cross-sectoral, health professional organizations, community leaders, religious leaders, NGOs or concerned people, and mass media in their working areas.

Cross programs are carried out by midwives and cadres when conducting classes for pregnant women to provide counseling for pregnant women, both those who are at a high risk or not about the existence of PONED health centers, while cross sectors such as districts and village heads are collected to provide information about the availability of PONED health centers serving 24 hours.

This is in line with the study conducted by Zulhadi (2013), which stated that several factors that lead to high public awareness are ongoing counseling conducted by Integrated Services Post midwives and cadres for pregnant women about high-risk pregnancy and and the danger caused.

Collaboration was also carried out with the Comprehensive Emergency Obstetric and Neonatal Care (PONEK) hospital as a place of reference. In Indonesia, the term "3 late" is very well known. It is the cause of maternal and neonatal deaths, namely late in decision-making at the family level, late in reaching service facilities and late in getting help at the health facility level. The existence of good cooperation with the hospital will facilitate the referral process so that the handling of emergencies will be faster.

\section{d. Inhibiting factors for the imple- mentation of PONED health centers}

The inhibiting factor will affect the service of PONED health center, so it must be addressed immediately so that the quality of service becomes better, the obstacles are the commitment of health workers who are not $100 \%$, the lack of public awareness to deliver at the community health centers, doctors are not in the health centerwithin 24 hours, claiming Healthcare Social Security Agency (BPJS) that is too long.

\section{Products}

\section{a. Client satisfaction with PONED health center services}

Services at the health centers can be declared of quality, if the service can provide satisfaction to its customers, meaning that what is obtained from the services received is in accordance with what is expected.

The service is said to be satisfactory if the expectations of its customers are fulfilled when receiving services and it is said to be excellent service if the services received exceed their expectations. If the expectations cannot be fulfilled, the service image becomes bad for the user. In this condition, technically, the service is not quality or the disease is not cured, but the personal/functional quality that has not been able to meet consumer demand (Ministry of Health, 2013).

\section{b. The benefit of PONED health center}

One effort to accelerate the reduction of MMR and NMR through emergency obstetric and neonatal management/complications at the basic service level is through efforts to implement PONED health centers.

Health services at the health centers have achieved the goal that patients who are in a fairly severe condition and / or in 
medical emergency conditions referred to the PONED health center facilities are served according to their competencies and authorities based on medical service standards and SOPs. If the patient cannot be treated thoroughly, it can be prepared and referred to on time and on purpose, so that the service can be adequately obtained at a more capable referral facility.

\section{REFERENCE}

Adi NP, Puspanegora A, Risma KK (2012). Efektifitas Sistem Rujukan Maternal dan Neonatal di Jakarta Timur. J Indon Med Assoc 62(11).

Atilda L (2012). Faktor-faktor yang berhubungan dengan rujukan kasus kegawatdaruratan obstertri neonatal oleh bidan desa ke puskesmas poned di Kabupaten Maluku Tengah. Jakarta: Universitas Indonesia.

Atmoko T (2008). Standar operasional prosedur dan akuntabilisasi kinerja instansi pemerintah. Unpad: Bandung

Bothamley J, Boyle M (2011). Patofisiologi dalam kebidanan. Jakarta: EGC.

Chabib T (2003). Teknik evaluasi pendidikan. Jakarta: Raja Grafindo Persada.

Cunningham FG (2005). Obstetri Williams. Jakarta : EGC.

Dinas Kesehatan Jawa Tengah (2013). Profil Kesehatan Provinsi Jawa Tengah 2013.

Dinas Kesehatan Kabupaten Tegal. (2014). Profil Kesehatan Kabupaten Tegal 2014.

Dinas Kesehatan Kabupaten Tegal (2015). Profil kesehatan kabupaten tegal 2015.

Eko PW (2009). Evaluasi program pembelajaran: panduan praktis bagi pendidik dan calon pendidik. Yogyakarta: Pustaka Pelajar.

Fraser DM, Margaret AC (2009). Buku ajar bidan. Jakarta : EGC.
Ghojazadeh M, Azami AS, Mohammadi M, Vosoogh S, Mohammadi S, Naghavi BM (2013). Prognostic risk factor for early diagnosing of preeclampsia in nulliparas. Nigerian Medical Journal.

Hamid H (2009). Evaluasi kurikulum (II). Bandung: Remaja Rosdakarya.

Handayani L (2006). Peran tenaga kesehatan sebagai pelaksana pelayanan kesehatan puskesmas. Buletin Penelitian Sistem Kesehatan. 13(1).12-20

Ivancevich, John M (2008). Perilaku dan Manajemen Organisasi, jilid 1 dan 2 Jakarta: Erlangga.

Kemenkes RI (2010). Meningkatkan profesionalisme PNS Kesehatan melalui diklat berbasis kompetensi. Badan pengembangan dan pemberdayaan SDM kesehatan

Kemenkes RI (2013). Pedoman penyelenggaraan puskesmas mampu PONED. Jakarta: Kemenkes RI.

Kementrian Perencanaan Pembangunan Nasional (2013). Evaluasi paruh waktu RPJMN 2010-2014. Jakarta: Kementrian Perencanaan Pembangunan Nasional.

Merviel P, Touzart L, Deslandes V, Delmas M, Coicaud M, Gondry J (2008). Risk factors of preeclampsia in single pregnancy. Journal Gyneology Obstetric Biologi 37(5): 477-482.

Mochtar R (2007). Sinopsis obstetri. Jakarta: EGC.

Moekijat (2013). Latihan dan pengembangan sumber daya manusia. Bandung: PT Mandiri Maju.

Moeloeng JL (2013). Metode penelitian kualitatif edisi revisi. Bandung: PT Remaja Rosda Karya.

Mujiati (2014). Kesiapan puskesmas poned (pelayanan obstetri neonatal emergensi dasar) di lima regional indonesia. Media Litbangkes 24 (1): 36-41. 
Nugroho T (2012). Patologi kebidanan. Yogyakarta: Nuha Medika.

Prawirohardjo S (2009). Ilmu kebidanan. Jakarta: PT.Bina Pustaka.

Ramesh K, Sangeetha G, Vishwas R (2014). Socio demographic and other risk factors of pre eclampsia at a tertiary care hospital, karnata: case control study. Journal of Clinicl and Diagnostic Research, 8(9): JCo1-JCo4.

Robson ES dan Waugh J (2011). Patologi dalam kehamilan, manajemen dan asuhan kebidanan. Jakarta: EGC.

Rozanna FR, Dawson A, Lohsoonthorn V, Williams MA (2009). Risk factors of early and late onset preeclampsia among thai women. Journal Medical Association 3(5): 477-486.

Rozikhan (2007). Faktor-Faktor Risiko Terjadinya Preeklamsi Berat Di Rumah Sakit Dr. H. Soewondo Kendal. Jurnal Ilmiah Universitas Diponegoro Semarang 10(3): 4-5.

Rukiyah Ai Y, Lia Y (2010). Asuhan kebidanan 4 ( Patologi ). Jakarta: TIM.

Saifuddin AB (2009). Buku acuan nasional pelayanan kesehatan maternal dan neonatal. Jakarta : PT. Bina pustaka.

SDKI. (2012). Survei demografi kesehatan indonesia 2012. Jakarta: Depkes RI.

Silva LM, Coolman M, Steegers EA, Jadde VW, Moll Ha, Hofman A, Mackenbach JP, Raat H. (2008). Low socioeconomic status is a risk factor for preeclampsia: the generatio study. Journal of Hypertension 26(6): 1200-8.

Sofian A (2011). Sinopsis Obstetri. Jakarta: EGC.

Sugiyono (2009). Metode Penelitian Kuantitatif Kualitatif Dan R\&D. Bandung: Alfabeta.
Suharsimi A, Cepi S (2009). Evaluasi program pendidikan: pedoman teoritis praktis bagi mahasiswa dan praktisi pendidikan, cetakan ketiga. Jakarta: Bumi Aksara.

Sularsih E (2009). Pengaruh pelatihan terhadap motivasi, sikap, ketrampilan bidan dalam pelaksanaan asuhan persalinan normal di wilayah Kabupaten Karanganyar. Tesis

Utama YS (2008). Faktor risiko yang berhubungan dengan kejadian preeklamsi berat pada ibu hamil di RSD Raden Mataher Jambi. Jurnal Ilmiah Universitas Batanghari Jambi 8(2): 2-4.

Wahyuni S, Budi I, Destriatania S (2014). Analisis sistem pelayanan obstetri dan neonatal emergensi dasar (PONED) di Puskesmas Tanjung Batu Kabupaten Ogan Hilir. Tesis: Universitas Sriwijaya.

Wijaya K (2012). Evaluasi persiapan puskesmas pelayanan obstetri neonatal emergensi dasar (PONED) di Kabupaten Brebes. Jurnal Kesehatan Masyarakat 1(2): 72-81.

Wulan AN (2012). Analisis implementasi program pelayanan obstetri neonatal emergensi dasar (PONED) Puskesmas Tlogosari Kulon dan Karangmalang Kota Semarang.Tesis

Yulifah R, Yuswanto TJA (2012). Asuhan kebidanan komunitas.Jakarta: Salemba Medika.

Zulhadi (2013). Problem dan tantangan puskesmas dan rumah sakit umum daerah dalam mendukung sistem rujukan maternal di Kabupaten Karimun Provinsi Kepri tahun 2012. Jurnal Kebijakan Kesehatan Indonesia 2(4). 